\title{
The anniversary conference "Structural Components of Forest Ecosystems: ecology, conservation and management" held in honour of Prof. Nicolae Doniță
}

\author{
Ecaterina Fodor ${ }^{1}$, Dan Gafta ${ }^{2}$, Florian Borlea ${ }^{3}$, Iovu Biriș
}

Fodor E., Gafta D., Borlea F., Biriș I., 2021. The anniversary conference "Structural Components of Forest Ecosystems: ecology, conservation and management" held in honour of Prof. Nicolae Doniță. Ann. For. Res. 64(1): 3-4.

The celebration of the outstanding personalities of academia is always an occasion to exchange ideas, establish the state of art of a scientific area, and highlight the hallmarks and new paradigms. This was the case of the Anniversary Conference "Structural Components of Forest Ecosystems: ecology, conservation and management" held in honour of Prof. Nicolae Doniță, under the generous auspices of the Banat University of Agricultural Sciences and Veterinary Medicine "King Michael I of Romania" in Timișoara. The celebrated scientist, Professor Nicolae Doniță (also member of the Romanian Academy of Agricultural and Forest Sciences "Gheorghe-Ionescu Șișești" and, Doctor Honoris Causa of the Agricultural and Veterinary Sciences University of Banat "King Mihai I of Romania" and of the University Ștefan cel Mare of Suceava) marked in that occasion his 90th anniversary, surrounded by his fellow scientists, former students and collaborators. Fifty-three participants in the conference honoured the personality and lifetime achievements of one of the most prominent figures among the Romanian forest ecologists, who reshaped the fundamentals of the Romanian silviculture based on the ecosystemic approach.

The most consistent section of the conference was dedicated to the presentation of oral communications and posters circumscribed to the conference's central theme. The systemic, holistic paradigm adopted in forest ecology was brought forward in the opening lecture given by Prof. Doniță: "On the formation of the forest ecosystem". The rest of presentations focused on more specific topics or case studies, of which some are briefly mentioned hereinafter. The old-growth forests in Romania were presented from the perspective of significance for the conservation efforts and various hindrances, with special reference to the integration in the larger European concern raised by climatic change and anthropogenic pressures. The forest dynamics in terms of species composition was employed as a tool for the evaluation of forest naturalness in Bosco Quarto (Gargano, Italy). The overview of tropical monospecific forest plantations brought a close insight into an old and controversial problem related to the balance between economic benefits and biodiversity loss. The study of the complex interactions between herbs and tree saplings in southern Appalachian forests revealed the mediator effects of soil fertility and stand evergreenness. The current status of forest habitats in Romania was summarized by means of the second national report to the European Commission (article 17 in the Habitats Directive). The importance of dead wood preserved in situ was demonstrated by the high diversity of saproxylic beetles within the natural reserve Voievodeasa Forest (North-Eastern Romania). The analysis 
of data contained in management plans was shown to provide useful information for mitigating the consequences of climatic change by improving the ecological status of forests and enhancing their environmental services. The synthesis on the old-growth and virgin beech forests from Carpathians and other European regions, included in the UNESCO World Heritage List, was presented as an important contribution to the forest conservation effort at European level. The role of soil physical and chemical properties, as important determinants for the distinction of forest ecosystem types, was highlighted in the Subsidiary Timiş Forest. The old-growth beech forests included in the nature reserve Izvoarele Nerei (South-Western Romania), famous for its big trees and pristine status, were shown to harbour a high biodiversity encompassing species from different groups. The comparison of two estimation methods of the foliar area index in a beechfir old-growth forest provided interesting insights on the influence of environmental factors.

The speakers referred to the scientific stature of Prof. Doniță, but also to his friendly human nature, his talent in gathering people around a common theme, his generous approach to science and scientists, being a leader but not misusing his authority, while always remaining a kind and patient guide. His achievements, spanning across six decades, consist of important international projects, seminal books and a vast array of scientific papers. Several outstanding books he coordinated or co-authored should be mentioned in this context: Forest Ecosystem Types of Romania (1990), Habitats of Romania (2005-2006), Forest Ecology (1978), The Vegetation of Romania (1992), Silviculture on Ecosystemic Bases (1997), The Virgin Forests of Romania (2001), Population, Species, Biocoenosis - An integrating Vision (2019). One of the milestones of Nicolae Doniță's activity was his participation in the project "Map of the Natural Vegetation of Europe, Scale 1:2500000, with Explanatory Text", which extended over 20 years of intensive collaboration between experts from across all Europe. Another notable achievement consisted in the elaboration (along with several co-workers) of the Forest Geospatial Database of Romania according to ecosystemic units and the corresponding digital map.

In conclusion, the conference gave the rare opportunity of gathering around a hallmark personality of forest ecology and a series of valuable scientific contributions, while celebrating the lifetime achievements of Prof. Doniţă in the context of the contemporary forest science. A selection of papers, either presented at the conference or submitted later on, are included in the first section of the current journal issue.

Addresses: ${ }^{1}$ Department of Forestry and Forest Engineering, University of Oradea, Oradea (Romania) $\mid{ }^{2}$ Department of Taxonomy and Ecology, Babeș-Bolyai University, Cluj-Napoca (Romania)| ${ }^{3}$ Department of Sustainable Development, Faculty of Agriculture, Banat University of Agricultural and Veterinary Sciences "King Mihai I of Romania", Timişoara (Romania) $\mid{ }^{4}$ Department of Soil Sciences, Faculty of Agriculture, University of Agronomic Sciences and Veterinary Medicine of Bucharest, Bucharest (Romania).

$\square$ Corresponding Author: Dan Gafta (dan.gafta@ubbcluj.ro). 